REGARDS

SUR L'ECONOMIE ALLEMANDE

BULLETIN ECONOMIQUE DU CIRAC
Regards sur l'économie allemande

Bulletin économique du CIRAC

$101 \mid 2011$

Varia

\title{
Réussir en Chine
}

WALDKIRCH K., Erfolgreiches Personalmanagement in China -

Rekrutierung, Mitarbeiterführung, Verhandlung / TIEU C. (dir.), Entre influences et échanges, réinventons une relation avec la Chine

\section{(2) OpenEdition}

Édition électronique

URL : http://journals.openedition.org/rea/4308

DOI : $10.4000 /$ rea. 4308

ISBN : 978-2-8218-0954-3

ISSN : 1965-0787

Éditeur

CIRAC

Édition imprimée

Date de publication : 10 juin 2011

ISSN : 1156-8992

\section{Référence électronique}

«Réussir en Chine », Regards sur l'économie allemande [En ligne], 101 | juin 2011, mis en ligne le 19 septembre 2011, consulté le 22 septembre 2020. URL : http://journals.openedition.org/rea/4308 ; DOl : https://doi.org/10.4000/rea.4308

Ce document a été généré automatiquement le 22 septembre 2020.

(c) CIRAC 


\section{Réussir en Chine}

WALDKIRCH K., Erfolgreiches Personalmanagement in China Rekrutierung, Mitarbeiterführung, Verhandlung / TIEU C. (dir.), Entre influences et échanges, réinventons une relation avec la Chine

\section{RÉFÉRENCE}

WALDKIRCH K., Erfolgreiches Personalmanagement in China - Rekrutierung, Mitarbeiterführung, Verhandlung, Gabler, Wiesbaden, 2009, 204 p.

TIEU C. (dir.), Entre influences et échanges, réinventons une relation avec la Chine, Dossier de La Revue Internationale et Stratégique, Institut de relations internationales et stratégiques (IRIS), n 81, Armand Colin, Paris, 2011, p. 69-182

1 Le manuel de management de K. WALDKIRCH sera profitable à tout responsable d'entreprise désirant s'implanter en Chine. L'auteur y prodigue de précieux conseils en termes de recrutement, de gestion du personnel et de négociation. Afin d'éviter, dans la mesure du possible, les écueils susceptibles d'apparaître dans un contexte interculturel. La Chine interpelle également de ce côté-ci du Rhin, où La Revue Internationale et Stratégique consacre un dossier spécial à la relation franco-chinoise. Pour évoquer les influences politiques et culturelles de l'Empire du Milieu, les échanges économiques bilatéraux et un cadre de coopération élargi. (sh) 